\title{
ANALISIS KINERJA TURBIN PROPELLER SEBAGAI ALAT PENGGERAK PADA PARUT KELAPA
}

\author{
Yeni Yusuf Tonglolangi \\ Fakultas Teknik, Program Studi Teknik Mesin, UKI Toraja \\ email: yeni.y.tonglolangi@gmail.com
}

\begin{abstract}
Abstrak
Kelangkaan energi listrik saat ini mendorong kita untuk memanfaatkan potensi alam yang ada untuk mengatasi masalah tersebut. Penelitian ini bertujuan untuk menganalisis kinerja turbin propeller sebagai alat penggerak pada parut kelapa, dimana turbin propeller ini memanfaatkan tumbukan air dan daya dorong air untuk menghasilkan energi listrik.

Dari hasil penelitian diperoleh bahwa semakin tinggi debit air, maka efisiensi yang dihasilkan semakin tinggi pula. Efisiensi maksimum diperoleh pada debit $0,016 \mathrm{~m}^{3} / \mathrm{s}$ yaitu sebesar $73,01 \%$.
\end{abstract}

Kata Kunci: Turbin propeller, energi listrik, debit air, dan efisiensi.

\section{PENDAHULUAN}

Dari waktu ke waktu kebutuhan energi cenderung semakin meningkat. Upaya untuk memperoleh energi listrik dapat di peroleh melalui beberapa metode konversi energi, misalnya dengan sistem Pembangkit Listrik Tenaga Diesel (PLTD), Pembangkit Listrik Tenaga Uap (PLTU), Pembangkit Listrik Tenaga air (PLTA) maupun sistem lainnya. Pemanfaatan energi tersebut disesuaikan dengan potensi alam yang tersedia dan besar kapasitas yang diinginkan. Untuk pemanfaatan air diperlukan sebuah alat yang bekerja dan menghasilkan energi listrik.

Menurut (Haimerl,1960) pemakaian jenis turbin Propeller lebih menguntungkan dibanding dengan pengunaan kincir air maupun jenis turbin mikro hidro lainnya karena ruangan yang di perlukan lebih kecil atau lebih kompak. Penggunaan turbin ini untuk daya yang sama dapat menghemat biaya pembuatan penggerak mula sampai $50 \%$ dari penggunaan kincir air dengan bahan yang sama, namun bahan-bahan yang di gunakan lebih murah karena menggunakan bahan dari wika yang transparan. Penghematan ini dapat dicapai karena ukuran turbin Propeller lebih kecil dan lebih kompak dibanding turbin lain. Turbin Propeller dapat dibuat hanya $\pm 20 \mathrm{~cm}$ saja sehingga bahan-bahan yang dibutuhkan jauh lebih sedikit, itulah sebabnya bisa lebih murah (Haimerl, 1960). Demikian juga daya guna atau effisiensi rata-rata turbin ini lebih tinggi dari pada daya guna kincir air. Tingginya effisiensi turbin Propeller ini akibat pemanfaatan energi air pada turbin ini dilakukan dua kali, yang pertama energi tumbukan air pada sudu-sudu pada saat air mulai masuk, dan yang kedua adalah daya dorong air pada sudu-sudu saat air akan meninggalkan runner. Adanya kerja air yang bertingkat ini ternyata memberikan keuntungan dalam hal effektifitasnya yang tinggi dan kesederhanaan pada sistim pengeluaran air dari runner. Penelitian ini bertujuan untuk menganalisis kinerja turbin propeller sebagai alat penggerak pada parut kelapa dengan variasi debit air.

\section{KAJIAN LITERATUR}

\subsection{Teori Turbin}

Turbin adalah mesin penggerak yang mengubah energi potensial fluida menjadi energi mekanik yang kemudian diubah lagi menjadi energi listrik pada generator. Bagian turbin yang berputar disebut runner atau roda turbin. Roda turbin terletak di dalam rumah turbin dan memutar poros daya yang menggerakkan generator listrik.

Pada roda turbin terdapat sudu dan fluida kerja mengalir melalui ruang diantara sudu 
tersebut. Sebuah roda turbin bisa saja terdapat beberapa baris sudu gerak yang dipasang berurutan dalam arah aliran fluida kerja, setiap baris sudu terdiri dari sudu yang disusun melingkar masing-masing dengan bentuk yang sama. Turbin dengan satu baris sudu gerak disebut turbin bertingkat tunggal, sedangkan turbin dengan beberapa baris sudu gerak disebut turbin bertingkat ganda. Proses fluida kerja mengalir melalui baris sudu yang pertama, kemudian baris kedua, ketiga dan seterusnya, namun sebelum mengalir ke setiap baris sudu yang bersatu dengan rumah turbin. Karena sudu tersebut tidak berputar, sudu tersebut disebut sudu tetap, yang berfungsi mengarahkan aliran fluida kerja masuk kedalam sudu gerak berikutnya, bisa juga disebut nossel (Haimerl, 1960).

Keuntungan - keuntungan turbin (Haimerl, 1960) antara lain :

1) Ruangan yang diperlukan lebih kecil atau lebih kompak.

2) Dapat beroperasi dengan kecepatan lebih tinggi.

3) Mampu membangkitkan daya yang lebih besar dengan ukuran yang relatif kecil.

4) Daerah putaran (rpm) yang lebih luas, sehingga memungkinkan hubungan langsung dengan generator.

5) Mampu memanfaatkan beda ketinggian permukaan air dari yang sangat rendah sampai yang lebih tinggi.

6) Dapat bekerja terendam di dalam air.

7) Mempunyai efisiensi yang relatif lebih baik.

8) Dapat dikonstruksikan dengan poros mendatar maupun tegak.

\subsection{Jenis-jenis Turbin}

Berdasarkan model aliran air masuk runner , maka turbin air dapat dibagi menjadi tiga tipe (Haimerl, 1960), yaitu:

1) Turbin Aliran Tangensial

Pada kelompok turbin ini posisi air masuk runner dengan arah tangensial atau tegak lurus dengan poros runner mengakibatkanrunner berputar, contohnya turbinpelton dan turbin Propeller.
2) Turbin Aliran Aksial

Pada turbin ini air masuk runner dan keluar runner sejajar dengan poros runner.Salah satu contoh dari tipe turbin ini adalah turbin kaplan atau turbin propeller.

3) Turbin Aliran Aksial - Radial

Pada turbin ini, air masuk ke dalam runner secara radial dan keluarrunner, secara aksial sejajar dengan poros. Turbin Francis adalah termasuk dari jenis turbin ini.

Dari segi pengubahan momentum fluida kerjanya, turbin dibagi dalam dua golongan, yaitu :

1) Turbin Reaksi

Turbin reaksi adalah turbin yang memanfaatkan energi potensial untuk menghasilkan energi gerak. Sudu pada turbin reaksi mempunyai profil khusus yang menyebabkan terjadinya penurunan tekanan air selama melalui sudu. Perbedaan tekanan ini memberikan gaya pada sudu sehingga runner dapat berputar. Ciri utama turbin reaksi pada semua jenis turbin, baik turbin uap, turbin gas maupun turbin air adalah sebagian tekanan jatuh terjadi pada sudu tetap dan sebagian lagi pada sudu berputar. Persamaan kontinuitas dapat digunakan pada perhitungan aliran melalui sudu berputar, karena seluruh fluida kerja memenuhi semua saluran sudu. Karena fluida masuk sudu berputar melalui seluruh tepi seksi masuk, maka untuk daya dan putaran yang sama, diameter nominalnya relatif lebih kecil dibandingkan dengan turbin impuls.

Turbin reaksi terdiri atas Turbin Francis, Turbin Propeller dan Turbin Kaplan

2) Turbin Impuls

Turbin impuls adalah turbin yang memanfaatkan energi potensial air diubah menjadi energi kinetik dengan nossel. Air keluar nossel yang mempunyai kecepatan tinggi membentur sudu turbin. Setelah membentur sudu, arah kecepatan aliran berubah sehingga terjadi perubahan momentum (impuls). Akibatnya roda turbin akan berputar.

Ciri utama turbin impuls adalah tekanan jatuh hanya terjadi pada sudu tetap, dan 
tidak terjadi pada sudu berputar, umumnya turbin impuls ini seluruh energi potensial di ubah menjadi energi kinetis didalam nozzle sebelum menerpa roda turbin, air yang keluar dari nozzle memancar dengan kecepatan-kecepatan tinggi diarahkan pada sejumlah sudu-sudu yang di pasang sekeliling roda turbin.

Turbin Impuls terdiri atas Turbin Pelton, Turbin Turgo, dan Turbin Propeller.

\subsection{Komponen-komponen Turbin Propeller}

Komponen-komponen turbin propeller terdiri atas:

a) Daun sudu-sudu turbin

Daun sudu-sudu turbin berbentuk lengkung yang bagian ujung-ujungnya dirangkai pada piring bulat perletakan sudu-sudu sehingga membentuk silinder sudu.

b) Piring sudu-sudu turbin

Berupa piringan berbentuk bulat yang diberi celah alur untuk penempatan daun sudu-sudu dan lubang bulat dibagian tengah untuk penempatan pipa sebagai poros silinder sudu, piring sudu-sudu ditempatkan pada poros silinder sudu-sudu.

c) Bearing

Bearing adalah bagian dari mesin, yang terbuat dari logam, yang berfungsi untuk memperkecil gesekan pada perputaran antara poros dengan rumah atau sebaliknya. Bearing juga berfungsi menumpu poros yang berbeban, sehingga putaran yang terjadi dapat berlangsung secara halus aman dan tahan lama dalam penggunaannya.

d) Poros

Poros merupakan suatu bagian yang terpenting dari sebuah turbin karena memiliki peranan penting dalam transmisi, yang meneruskan daya ke bagian-bagian yang lain. Untuk meneruskan daya poros diklasifikasikan menurut fungsinya yaitu poros transmisi, poros spindle, dan gandar. Sesuai dengan fungsi dan kegunaannya, maka dalam perancangan ini poros yang digunakan adalah jenis poros transmisi karena daya yang ditransmisikan kepada poros melalui puli dan sabuk.

\subsection{Keunggulan dan Kelemahan Turbin Propeller}

Keunggulan-keunggulan dari turbin Propeller dibandingkan dengan turbin jenis lainnya adalah:

1) Kisaran operasi yang luas

Kisaran operasi pada turbin Propeller meliputi debit antara 20 sampai 10.000 liter per detik, serta head antara 1 sampai 200 m. Turbin Propeller dapat beroperasi pada berbagai debit dibandingkan dengan jenis turbin lainnya. Dengan adanya kisaran operasi yang luas maka turbin Propeller memungkinkan untuk dipakai pada berbagai PLMTH yang debit dan head-nya berbeda.

2) Sebagai alternatif turbin francis

Dengan kisaran operasi yang luas, turbin Propeller dapat menjadikan alternatif menggantikan turbin prancis yang dulunya sering digunakan sebagai penggerak mula PLTMH.

3) Pengaturan efisiensi yang tetap tinggi pada debit rendah

Turbin Propeller mempunyai keunggulan di mana dapat diatur agar efisiensinya tetap tinggi meskipun aliran sangat kecil, misalnya hanya seperempat atau $25 \%$ dari debit aliran penuh.

4) Mudah dan murah proses pabrikasi dan pemeliharaan

Turbin Propeller merupakan turbin air jenis impuls yang berbeda dengan turbin reaksi yang tidak memerlukan casing yang mampu menahan tekanan tinggi, juga memerlukan clearance yang sangat tinggi. Dengan sifat-sifat tersebut, turbin ini lebih gampang dipabrikasi dan dipelihara. Artinya dalam pemeliharaannya tidak memerlukan teknisi dan peralatan yang khusus (www.microhydropower.net).

Disamping keunggulan-keunggulannya, turbin Propeller juga memiliki keterbatasan dalam penggunaannya,seperti:

1) Efisiensi yang lebih rendah

Masing-masing jenis turbin memiliki kurva efisiensi yang berbeda jika beroperasi pada berbagai macam debit aliran air. Sebuah turbin biasanya didesain 
untuk beroperasi pada titik efisiensi terbaiknya. Jika turbin beroperasi pada debit yang lebih rendah atau lebih tinggi dari titik efsiensi terbaiknya maka efisiensi hidrauliknya akan turun.

2) Pengaturan secara load control

System pengaturan pada pembangkit listrik mempunyai fungsi agar jumlah listrik yang dihasilkan sama dengan jumlah listrik yang dikonsumsi, sehingga kualitas listrik yang dihasilkan berupa tegangan dan frekuensi tetap terjaga. Untuk itu ada dua jenis sistem pengaturan pada listrik tenaga air, yaitu:

a. Pengaturan debit air (flow control)

b. Pengaturan beban listrik (load control, British Hydro Association).

Rumus-rumus yang digunakan dalam pengujian ini adalah sebagai berikut:

\section{a. Debit air}

Untuk mengetahui besarnya volume air yang mengalir. Volume air yang mengalir disebut debit air. Debit air yang mengalir, dapat dihitung dengan menggunakan persamaan:

$$
Q=\frac{V}{t}
$$

Keterangan:

$$
\begin{aligned}
\mathrm{Q} & =\operatorname{Debit} \operatorname{air}\left(\mathrm{m}^{3} / \mathrm{s}\right) \\
V & =\operatorname{Volume}\left(\mathrm{m}^{3}\right) \\
& =2 \cdot \pi \cdot r^{2} \cdot \mathrm{h} \\
t & =\operatorname{Waktu}(\mathrm{s})
\end{aligned}
$$

\section{b Kecepatan air}

Kecepatan air merupakan ukuran banyaknya volume air yang dapat lewat dalam suatu tempat atau yang dapat di tampung dalam suatu tempat tiap satu satuan waktu. Aliran air dikatakan memiliki sifat ideal apabila air tersebut tidak dapat dimanfaatkan dan berpindah tanpa mengalami gesekan, hal ini berarti pada gerakan air tersebut memiliki kecepatan yang tetap pada masing-masing titik dalam pipa dan gerakannya beraturan akibat pengaruh gravitasi bumi. kecepatan air dapat dihitung dengan rumus:

$$
v=\frac{Q}{A}
$$

Keterangan

$v=$ Kecepatan air $(\mathrm{m} / \mathrm{s})$

$\mathrm{Q}=$ Debit $\operatorname{air}\left(\mathrm{m}^{3} / \mathrm{s}\right)$

$\mathrm{A}=$ Luas penampang sudu turbin $\left(\mathrm{m}^{2}\right)$

$$
=\pi \cdot r^{2}
$$

\section{c. Massa jenis}

Massajenis adalah pengukuran massa setiap satuan volume benda. Semakin tinggi massa jenis suatu benda, maka semakin besar pula massa setiap volumenya, maka dapat dituliskan persamaan sebagai berikut:

$\rho=\frac{m}{V}$ atau $\mathrm{m}=\rho \mathrm{x} \mathrm{V}$

Keterangan:

$\rho=$ Rapat massa air $=980 \mathrm{~kg} / \mathrm{m}^{3}$

$m$ =Massa air $(\mathrm{kg})$

$V=\operatorname{Volume}\left(\mathrm{m}^{3}\right)$

\section{d. Daya air}

Menghitung daya air dilakukan untuk mengetahui daya air yang akan digunakan, sehingga di dapatkan efisiensi penggunaan daya tertentu yang dapat dirumuskan sebagai berikut:

$$
P_{\text {air }}=\rho \times g \times Q \times H
$$

Keterangan :

$\mathrm{P}_{\text {air }}=$ Daya air(Watt $)$

$\rho=$ Rapat massa $\left(\mathrm{kg} / \mathrm{m}^{3}\right)$

$\mathrm{H}=$ Tinggi $(\mathrm{m})$

$\mathrm{g}=$ Gravitasi bumi $\left(\mathrm{m} / \mathrm{s}^{2}\right)$

$\mathrm{Q}=$ Debit air $\left(\mathrm{m}^{3} / \mathrm{s}\right)$

\section{e. Daya turbin}

Perhitungan daya turbin yang dapat dihasilkan oleh sebuah turbin air dengan persamaan sebagai berikut:

$\mathrm{P}_{\mathrm{t}}=\tau \times \omega$ atau $\mathrm{P}_{\mathrm{t}}=\mu \times \mathrm{P}_{\text {air }} \ldots \ldots$

Keterangan :

$\mathrm{P}_{\mathrm{t}}=$ Daya turbin (Watt)

$\tau=$ Torsi $(\mathrm{Nm})$

$\omega=$ Kecepatan angular $(\mathrm{rad} / \mathrm{s})$

$\mathrm{P}_{\text {air }}=$ Daya air (Watt) 


\section{f. Daya generator}

Daya generator merupakan daya yang dihasilkan dari perkalian antara kuat arus dengan tegangan yang dihasilkan oleh turbin dengan persamaan berikut:

$\mathrm{PG}=\mathrm{I}$. V

Keterangan:

$\mathrm{PG}=$ Daya generator(Watt)

$\mathrm{I}=$ kuat arus(Ampere)

$\mathrm{V}=$ tegangan $($ Volt $)$

\section{g. Daya alat parut kelapa}

Perhitungan daya alat parut kelapa yang dapat di hasilkan oleh mesin parut kelapa dengan persamaan sebagai berikut:

$$
P \mathrm{k}=\mathrm{I} \times \mathrm{V}
$$

Keterangan:

$$
\begin{aligned}
& P \mathrm{k}=\text { kuat arus parut kelapa (Watt) } \\
& \mathrm{I}=\text { kuat arus listrik (Ampere) } \\
& \mathrm{V}=\text { tegangan listrik (Volt) }
\end{aligned}
$$

\section{h. Efisiensi turbin}

Efisiensi yang dihasilkan turbin air dapat dihitung dengan persamaan sebagai berikut:

$$
\eta=\frac{P_{t}}{P_{\text {air }}} \times 100 \%
$$

Atau

$$
\eta=\frac{P_{G}}{P_{\text {air }}} \times 100 \% \ldots \ldots \ldots \ldots . .(7)
$$

Keterangan :

$\eta=$ Efisiensi turbin (\%)

$\mathrm{P}_{\text {air }}=$ Daya air(Watt $)$

$\mathrm{P}_{\mathrm{t}}=$ Daya turbin (Watt)

$\mathrm{P}_{\mathrm{G}}=$ Daya generator (Watt)

\section{METODE PENELITIAN}

Desain komponen utama dari turbin Propeller antara lain:

1. Pembuatan piringan

Bahan yang digunakan adalah wika. Lankah-langkah yang digunakan adalah:

a. Wika dipaotong berbentuk persegi.

b. Wika dibentuk seperti lingkaran dengan menggunakan mesin gerinda dan mesin bubut.

c. Piringan tersebut dirangkai menyatu dengan sudu dan poros turbin.
2. Pembuatan sudu-sudu turbin

Bahan yang digunakan adalah wika yang dibuat dengan langkah-langkah sebagai berikut:

a. Wika dipotong dengan ukuran lebar yang telah ditentukan pada desain penelitian dengan menggunakan mesin gerinda.

b. Setelah pemotongan dilakukan, wika tersebut direbus sampai bisa dilengkungkan.

c. Wika tersebut dipotong-potong sama panjang.

d. Sudu tersebut dirangkai pada piringan dengan menggunakan lem.

3. Pembuatan dudukan turbin

Bahan yang digunakan adalah besi siku 25 $\mathrm{mm}$ x $25 \mathrm{~mm}$. Besi tersebut dipotong dengan menggunakan mesin gerinda, kemudian dirangkai membentuk persegi panjang dengan menggunakan mesin las. Tahap terakhir dilakukan pengecatan.

4. Instalasi pipa

Pipa yang digunakan adalah pipa ukuran 1,5 inchi. Pipa dipotong dengan gergaji besi. Setelah itu, pipa tersebut dirangkai menyatuh dengan nossel dan pompa.

Dalam pelaksanaan pengambilan data digunakan prosedur-prosedur sebagai berikut:

1. Mengalirkan air sesuai kebutuhan turbin Propeller.

2. Memeriksa kembali semua komponen alat apakah sudah terpasang dengan baik dan benar.

3. Mengukur debit yang dihasilkan, yaitu menghitung waktu dan putaran turbin.

4. Prosedur pengambilan data diatas dilakukan sebanyak tiga kali dengan bukaan katup 50\%, 75\% dan 100\% untuk mendapatkan data yang lebih akurat.

\section{HASIL DAN PEMBAHASAN}

\subsection{Hasil Penelitian}

Tabel 4.1. Data Penelitian

\begin{tabular}{|c|c|c|c|c|c|c|c|}
\hline No & $\begin{array}{c}\text { Pembukaan } \\
\text { pintu air }\end{array}$ & $\begin{array}{c}\mathrm{h} \\
(\mathrm{m})\end{array}$ & $\begin{array}{c}\mathrm{t} \\
(\mathrm{s})\end{array}$ & $\begin{array}{c}\mathrm{V} \\
(\text { volt })\end{array}$ & $\begin{array}{c}\mathrm{I} \\
(\text { Ampere })\end{array}$ & $\begin{array}{c}\rho \\
\left(\mathrm{kg} / \mathrm{m}^{3}\right)\end{array}$ & $\begin{array}{c}\mathrm{g} \\
\left(\mathrm{m} / \mathrm{s}^{2}\right)\end{array}$ \\
\hline 1 & 100 & 30 & 120,21 & 97 & 0,5 & 980 & 9,81 \\
\hline 2 & 100 & 40 & 100,37 & 100 & 0,5 & 980 & 9,81 \\
\hline 3 & 100 & 50 & 85,42 & 150 & 0,5 & 980 & 9,81 \\
\hline 4 & 100 & 60 & 60,55 & 190 & 0,5 & 980 & 9,81 \\
\hline
\end{tabular}


Table 4.2. Hasil Perhitungan

\begin{tabular}{|c|c|c|c|c|c|c|c|c|}
\hline $\mathbf{N o}$ & $\begin{array}{c}\mathbf{Q} \\
\left(\mathbf{m}^{3} / \mathbf{s}\right)\end{array}$ & $\begin{array}{c}\text { Volu- } \\
\mathbf{m} \mathbf{m} \\
\left(\mathbf{m}^{3}\right)\end{array}$ & $\begin{array}{c}\text { Massa } \\
(\mathbf{k g})\end{array}$ & $\begin{array}{c}\mathbf{P}_{\text {air }} \\
(\mathbf{W})\end{array}$ & $\begin{array}{c}\mathbf{P}_{\text {turbin }} \\
(\mathbf{W})\end{array}$ & $\begin{array}{c}\mathbf{P}_{\text {gen }} \\
(\mathbf{W})\end{array}$ & $\begin{array}{c}\mathbf{P}_{\mathbf{k}} \\
(\mathbf{W})\end{array}$ & $\begin{array}{c}\eta \\
(\mathbf{\%})\end{array}$ \\
\hline 1 & 0,016 & 0,050 & 48,914 & 376,683 & 288,40 & 275 & 48,5 & 76,56 \\
\hline 2 & 0,019 & 0,060 & 58,583 & 451,141 & 346,09 & 275 & 50 & 76,71 \\
\hline 3 & 0,022 & 0,070 & 68,836 & 530,098 & 423,00 & 275 & 75 & 79,80 \\
\hline 4 & 0,031 & 0,099 & 97,110 & 747,828 & 596,04 & 275 & 95 & 79,70 \\
\hline
\end{tabular}

\subsection{Pembahasan}

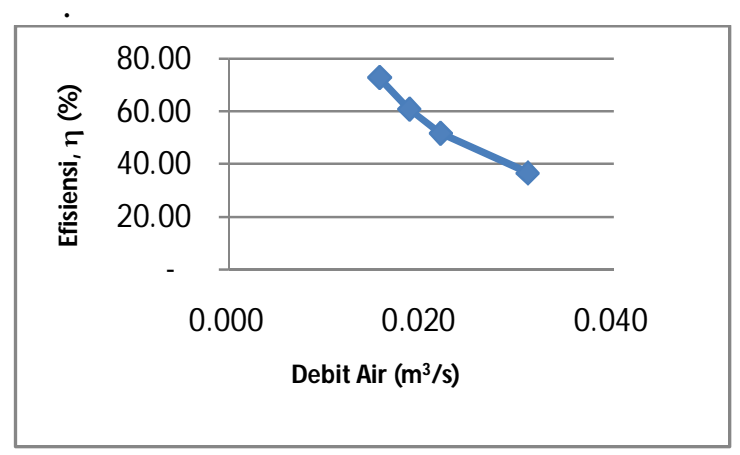

Grafik 4.1. Pengaruh Debit Air terhadap Efisiensi

Pada grafik di atas dapat dilihat pengaruh debit air terhadap efisiensi turbin. Semakin tinggi debit air, maka efisiensi turbin cenderung menurun. Nilai efisiensi maksimum terjadi pada debit air $0,016 \mathrm{~m}^{3} / \mathrm{s}$ yaitu sebesar 73,01\%.

Pada umumnya mesin penggerak parut kelapa menggunakan mesin berbahan bakar bensin atau solar, bukan tidak mungkin ini membutuhkan biaya yang besar lagi sehingga dengan adanya sumber tenaga air yang ramah lingkungan serta tidak membutukan biaya yang terlalu besar, maka kita bisa menciptakan energi kinetik dari aliran air menjadi energi listrik,dalam pengujian yang dilakukan terhadap turbin propeller sebagai penggerak alat parut kelapa. Debit air sangat menentukan besar kecilnya daya yang di hasilkan untuk memutar turbin. Daya/energi yang di hasilkan oleh turbin untuk memutar mesin parut kelapa yaitu diatas 210 watt, maka ketinggian air dalam bak penampungan diatas $60 \mathrm{~cm}$. Turbin baru bisa beroperasi/mampu memutar mesin parut kelapa bila menghasilkan daya diatas 210 watt. Pada pengujian pertama turbin tidak mampu beroperasi karena daya yang di hasilkan hanya sedikit karena ketinggian air dalam bak penampungan hanya $45 \mathrm{~cm}$.

\section{KESIMPULAN}

Dari hasil penelitian dan analisa data dapat disimpulkan bahwa semakin tinggi debit air, maka efisiensi yang dihasilkan semakin tinggi pula. Efisiensi maksimum diperoleh pada debit $0,016 \mathrm{~m}^{3} / \mathrm{s}$ yaitu sebesar $73,01 \%$.

\section{REFERENSI}

Arismunandar, 1982. Teknik Tenaga Listrik jilid 1. Pradya paramitha Jakarta.

Boyle. Godfrey, Renewable Energi, Power for a Sustainable Future. Oxford UniversityPress, 1996.

Dietzel, Frits, Dakso Sriono (1996).Turbin, Pompa dan Kompresor (terjemahan). Erlangga, Jakarta

Harinaldi, Budiarso. (2004). Mekanika Fluida edisi keempat: Erlangga, Jakarta.

Masters. Gilbert M., Renewable and Efficient Electric Power Systems. John Wiley \&Sons, Ltd, 2004.

Munson. R. Bruce dan Budiarso, (2003). Mekanika Fluida (terjemahan) Edisi keempat, jilid 1, Erlangga, Jakarta.

Pandekter, MM, Setyady B, 1991, Pembangkit Listrik Tenaga Air. Ul-PRESS Jakarta.

Prayatmo Wibowo. (2007). Turbin Air : Graha Ilmu, Yogyakarta.

Pudjanara, Astu dan Nursudud, Djati. Mesin Konversi Energi. Yokyakarta : ANDI, 2008.

Streeter, V. L., Benjamin., Prijono., Arko. 1999. Mekanika Fluida (Terjemahan) edisi Delapan, Penerbit Erlangga Jakarta.

Sriyono Dakso. (1996). Turbin, Pompa dan Kompresor: Erlangga, Jakarta.

White, M.Frank, Manahanhariandja (1998). Mekanika Fluida (terjemahan). Erlangga, Jakarta. 
